\title{
21. VOLCANIC ROCKS FROM THE WESTERN AND CENTRAL PACIFIC: LEG 7, DEEP SEA DRILLING PROJECT
}

\author{
Ralph Moberly, Jr., Hawaii Institute of Geophysics, University of Hawaii, Honolulu, Hawaii \\ and \\ G. Ross Heath, Department of Oceanography, Oregon State University, Corvallis, Oregon
}

\begin{abstract}
Basalt was recovered below the sedimentary section at sites in the Mariana Basin, Eauripik Ridge, East Caroline Basin, and Central Pacific Basin. The basalt at Eauripik Ridge was intrusive and dolomitized the overlying limestone. Other rocks with an origin related to volcanism, recovered at these or other sites between Guam and Hawaii, include pyroclastic, hyaloclastic, turbidite epiclastic, and nonturbidite epiclastic volcanic sediments.
\end{abstract}

\section{INTRODUCTION}

Detailed petrographic and geochemical studies of volcanic rocks sampled during all the Deep Sea Drilling Project cruises will be the responsibility of a separate panel of scientists. This brief description is based on a few thin sections prepared and examined on board the D/V Glomar Challenger. Many of the alteration products of the rocks are so fine grained that positive mineral identification in thin-section is impossible.

The authors appreciate the comments of Robert Berry, who examined thin sections of two of the basalts after the completion of Leg 7.

\section{BASALT}

\section{Site 61}

During the redrilling of Site 61 in the southwestern Mariana Basin, the bit penetrated through a layer of basalt. Next it went through an unrecovered section that was soft, presumably sediment, and then hard, presumably another layer of basalt. No contacts were cored, but the lack of evidence of low-grade thermal metamorphism of the sediments a few meters above the basalt suggests that the sediments were deposited on a flow. Alternation of flows and sediments suggests that Cretaceous volcanism and pelagic sedimentation overlapped in time at Site 61, as was discussed more fully in the Site Report in this volume.

About 2 meters of basalt was recovered in the first hole and 0.6 meter in the redrill. Megascopically, the rock is light gray, nonporphyritic, and characterized by amygdules. The amygdules are largest, most abundant and most irregular in shape in the uppermost part of the core. They are mainly spherical and about 5 millimeters in diameter, but range up to 22 millimeters in diameter.
Microscopically, the rock is a coarse basalt or microgabbro, with grains dominantly between 0.6 and 1.0 millimeters (Figure 1). The texture is intersertal. Grains of feldspar and of pyroxene are subhedral. Magnetite euhedra are inclusions in both the feldspar and the pyroxene and on grain boundaries between them. The feldspar laths are larger and more abundant than the pyroxene grains. The groundmass is entirely altered.

The feldspar grains average 0.8 to 0.9 millimeter in length and 0.3 millimeter in width. Albite twinning is present, but Carlsbad twinning is more common. Many of the feldspar laths exhibit normal zoning from core to rim. The feldspar is laboradorite of about An 60 . Good optical figures are uncommon from these sections; composition based on $2 \mathrm{~V}$ estimations and one $a$ $\Lambda(001)$ on (010) figure is An 65 or less.

Pyroxene grains are pale brown and about 0.6 to 0.7 millimeter in size. The pyroxene is augite with an approximate composition of $\mathrm{Ca}_{32} \mathrm{Mg}_{5}{ }_{3} \mathrm{Fe}_{15}$, as estimated using acute bisectrix figures and one good $\mathrm{Z} \Lambda \mathrm{C}$ extinction angle. Magnetite is present as 0.1 to 0.2 millimeter euhedral grains and as dust. Biotite and chlorite blades average 0.1 millimeter in length in the altered areas. A few grains of calcite and basaltic hornblende are present.

About one-fourth of each thin section shows distinct alteration to masses of one or more pale green minerals present in radiating and plumose bundles of needles (Figure 2). The needles average 0.02 millimeter in length and are of low birefringence and have nearly parallel or parallel extinction. Parts of freshly-cut surfaces of these basalts swell when wet with water, and so part or all of the acicular green mineral probably is montmorillonite. However, some may include clinozoisite, epidote, actinolite, or a combination of those minerals. If they are present to any 
extent the alteration might be termed saussuritization, even though saussurite commonly is accompanied by albitization, which is not present here. Most of the alteration is of the groundmass, which may have been glass originally. Some is present in the feldspars, especially along cleavages and edges (Figure 3). A few pyroxene grains are partly altered and the alteration product is identical to that of the groundmass and plagioclase. If actinolite is indeed present in the alteration product the term uralitization might be applied for the alteration of the pyroxene, but fine grain size precludes positive identification of the pale green acicular minerals.

\section{Site 62}

The slight amount of basalt cored at the south end of Eauripik Ridge is strongly altered. Its color is mainly dark gray, and ranges to shades of brownish gray and greenish gray where most altered. The basalt is slightly vesicular and is irregularly veined with carbonate that has filled into cracks and joints up to 2 millimeters in width. Dolomitization of the overlying chalky limestone is evidence of the intrusive origin of the basalt. These and other effects on carbonates are described in the second section of this paper.

The texture of the basalt originally was hypocrystalline and hypidiomorphic, and the composition was plagioclase, pyroxene, and olivine, with lesser magnetite or ilmenite, in a groundmass of plagioclase microlites and glass (Figure 4). The plagioclase feldspar is lath-shaped and there is little or no hiatus in the range of grain size from 0.2 millimeter-long microlites in the mesostasis to the maximum grain size of about 1.8 millimeters in length; grains 0.6 to 0.9 millimeter in length are most common. The texture is moderately glomerophorphyritic, with some of the clots of feldspar characteristically radial about a pyroxene or olivine core. Most of the feldspar has been replaced by fine aggregates of chlorite and probably montmorillonite, so that the composition cannot be determined closely. Apparently it is less calcic than An 70 .

The pyroxene also is mainly replaced, by chlorite, montmorillonite (?), epidote (?), and iron oxides. The few unaltered patches of grains are not sufficiently large to allow estimation of $2 \mathrm{~V}$. Unaltered pyroxene is nonpleochroic and very pale green. Olivine euhedral phenocrysts are entirely replaced, by iddingsite, chlorophaeite, and a serpentine mineral.

The texture of the interstitial groundmass is not understood. Two components are present (Figures 4 and 5). One of these is irregular bleb-shaped, clear pale green masses. Their composition is montmorillonite, as fibers normal to the edges of the blebs and grading into irregular masses in the center. The blebs range from about 0.06 to more than 1 millimeter across. The larger ones commonly show two or more layers of the fibrous montmorillonite. The general appearance is of irregular vesicules that have first been lined, and later filled, with montmorillonite. However, true spherical vesicules are present, now also rimmed with chlorite and montmorillonite (?) blades, and with clear, irregular granular masses of analcite in them. The pale green blebs cut vesicule walls and seemingly intrude them. The second of the two components is plumose to irregular masses of chlorite, epidote (?), and biotite, heavily charged with opaque dust. Often the plumes, fans, and comb-like blades radiate from feldspar or other phenocrysts (Figure 6). This component is interpreted as being devitrified, perhaps deuterically altered, glass. In some parts of each thin section the devitrified glass is distinctly more abundant than the pale green blebs, whereas elsewhere the reverse is true.

\section{Site 63}

More than 3 meters of basalt was recovered in cores from Site 63, near the eastern edge of the East Caroline Basin. The contact of the overlying nannofossil marl on the basalt is depositional. Masses of recrystallized carbonate within the basalt are xenoliths of earlier sediment ingested by the basalt.

The basalt is dark gray and porphyritic. Vesicules of about 0.3-millimeter diameter are common in the uppermost part. They are fewer and smaller a meter or so below the top contact.

The texture is intersertal. Feldspar and pyroxene are present both as phenocrysts and in the groundmass. The phenocrysts total about 5 per cent of the rock; some are glomerocrysts (Figures 7 and 8 ). The feldspar is labradorite with composition about An 55; some cores of albite-twinned normal-zoned phenocrysts is bytownite. Carlsbad twins dominate both phenocrysts and groundmass feldspars. The feldspar phenocrysts are euhedral to subhedral laths, 0.6 to 1.2 millimeters in length and 0.3 to 0.5 millimeter in width, whereas the groundmass laths are subhedral and mainly less than 0.1 millimeter in length and 0.02 millimeter in width. Feldspars are free of inclusions and show slight normal zoning. In one thin section some feldspar phenocrysts apparently had been partly resorbed in their history. The phenocrysts have irregular extinction and embayed inner cores surrounded by euhedral overgrowths that are not optically continuous with the cores (Figures 9 and 10).

Pyroxene phenocrysts are mainly subhedral, free of inclusions, and unaltered, and about 0.3 to 0.6 millimeter in diameter (Figure 8). Groundmass pyroxene is anhedral, also free of inclusions and unaltered, and with a maximum diameter of about 0.04 millimeter. Magnesian pigeonite is more common than augite. The groundmass also contains prismatic needles 
of magnetite, commonly in radiating bundles. A few magnetite octahedra are present. A small percentage of the rock is now a light green mineral, present as very fine-grained aggregates whose irregular shapes average 0.2 millimeter across. Probably it is a montmorillonitic alteration of glass.

\section{Site 66}

Less than a meter of basalt was drilled at the base of Hole 66.0, and only a few fragments of altered basalt were recovered in the core catchers. The basalt is yellowish brown from iron oxides and clay, and slightly vesicular.

In thin section the texture is intersertal; there are patches where there is sufficient alignment of feldspar microlites to suggest pliotaxitic texture. Phenocrysts of feldspar and pyroxene are present but rare.

Plagioclase microlites as laths about 0.2 millimeter in length make up the main crystalline part of the rock (Figure 11). Many grains are partly altered and most have finely corroded edges. The interstices are filled with brownish masses of clays, iron oxides, chlorite, and other minerals that formed from the glass, pyroxene, and magnetite. Most is in vague cryptocrystalline clots, but some "limonite" is pseudomorphic after finely prismatic magnetite, or, in interpenetrating sets of needles to 0.03 millimeter long, after pyroxene. The fine grain size and alteration precluded accurate optical determination of mineral compositions; the plagioclase is more calcic than An 55 .

Small vesicules are abundant in the fragments recov ered, which were at the top of a flow. Vesicules are lined or filled with finely-bladed to acicular montmorillonite (Figure 12). Veinlets of ferromanganese oxides permeate the basalt.

\section{OTHER ROCKS FORMED OR INFLUENCED BY VOLCANISM}

\section{Site 61}

Fragments of olive-gray tuff of Late Cretaceous age were common in the cores recovered below 72 meters, and in the material extruded from the bumper subs after abandoning the site. The tuff is finely laminated and has a grain size of 0.1 millimeter or less. Pale-brown, nonpleochroic pyroxene and yellowishbrown, fresh-appearing mafic glass shards are characteristic. Plagioclase and some chlorite are present. The volcanic grains are in a matrix of fine-grained swelling clay that imparts the light color to the rock.

The abundant cristobalitic porcelanite at Site 61 probably was originally a radiolarian-rich silty ash.

\section{Site 62}

Glass shards were common in cores at several depths from most sites. Less common were pumice lapilli and ash beds, and they were generally not sampled on board ship in order to save as large a portion as possible for later radiometric and geochemical studies. The vitric ash bed at 98 meters at Site 62 is about 6 centimeters thick, and is olive-black from pyrite that has grown on shard surfaces as seen in smear slides. The sand-sized glass has a refractive index of about 1.518 and is fresh.

The chalky limestone below about 570 meters has been metasomatized to dolomite, by the subjacent intrusion of basalt. Unreplaced foraminifers in the upper part of the dolomite section (Figure 13) and clay-rich laminae that retain the original wispy bedding are evidence of the sedimentary origin of the carbonate that has been altered. The dolomite is friable and its euhedral rhombs have a generally uniform grain size of about 0.5 millimeter.

\section{Site 63}

The basalt at Site 63 was extrusive, but had ingested some masses of limestone that now show effects of both contact metamorphism and later alteration. Thin sections across the contact show the basalt-limestone contact to be irregular, with a few veinlets of basalt into the limestone. The contact characteristically has hematite flakes and ferromanganese oxides in a zone 0.01 to 0.04 millimeter thick. Within 0.1 millimeter of the contact recrystallization of the chalk is the only apparent evidence of metamorphism. However, the basalt for about 0.2 millimeter next to the contact is a vermiform aggregation of acicular and finely-bladed brown chlorite and pale green montmorillonite. They are alteration products of a thin glassy, variolitic selvage. Near the contact the plagioclase phenocrysts are altered to montmorillonite, and pyroxene grains have coronas of needles of green amphibole (actinolite?) radiating from them. Veinlets of actinolite or serpentine are also present there. Skarn-like patches also characterize the boundary between basalt and ingested sediment (Figures 14 and 15). They contain masses of montmorillonite rosettes that are pseudormorphic after 0.04 millimeter-long prisms of scapolite (?). The prisms are edged by radiating blue-green chlorite needles which become browner toward the center of the patches.

Small masses of chalk ingested in the basalt are almost completely recrystallized to pale red-brown and pale green marbles. They are composed of calcite with lesser montmorillonite and clinoptilolite. Rare coccoliths and calcite mosaic pseudomorphs of foraminifers indicate that the carbonate originally was sedimentary. 


\section{Site 65}

Grains of palagonite and other volcanic debris are abundant in many of the thin turbidite beds at Site 65 in the western part of the Central Pacific Basin. They are described in the chapter on deep-sea turbidites by Heath and Moberly, in this volume. Sediments are as coarse as 3 millimeters in grain diameter in the volcanic sandstone recovered as fragments in the core catcher of Core 17, Hole 65.0.

\section{Site 66}

The basalt at the base of the section at Site 66 is overlain by about 5 meters of multicolored altered hyaloclastite and chemical sediments.

The rock mainly is a stiff to crumbly mudstone, but complex in texture and coloring. The present grain size ranges from angular fragments of altered basalt as coarse as 4 centimeters in diameter, to clay grains less than 0.001 millimeter in diameter. Much of the rock was formed as grains 1 to 0.05 millimeter in diameter, as evidenced by the grainy feel of broken surfaces and as seen under the binocular microscope or in impregnated thin sections. Colors are mainly reddish brown to brownish black, with the darker shades depending on the ferromanganese-oxide content, but mottled and speckled yellows, greens, browns, and oranges are also present.

Most of the rock appears to be an altered hyaloclastite, whose original sand-sized angular grains of basalt glass are now palagonite or replaced by fine-scale intergrowths of microcrystalline to cryptocrystalline iron oxides and montmorillonite (Figure 16). A thin colloform-like coating of acicular radiating zeolite edges many grains. The matrix is a mosaic of clay-sized acicular montmorillonite.

The hyaloclastite contains lenses (Figure 17) to beds and masses as thick as 0.5 meter of fine clay that is heavily charged with fine ferromanganese oxides. The proportion of hyaloclastite fragments to ferromanganese clay varies widely (Figures 18 and 19). Some of the grains are of little-altered glass and feldspar, and of fish debris. The intimate association of the inorganically-precipitated oxides with hyaloclastite and basalt breccia suggests a possible source of some of the metals from volcanic exhalations.

\section{Site 67}

Most of the sediment recovered from the Hawaiian Arch is volcanogenic in origin. All the recovery was of grains and pieces broken by the bit (Figure 20); there were no cores cut by the bit. Although the largest fragments were only a few centimeters in length, they commonly had preserved some bedding-plane structures. Dark-reddish-brown volcanic sandstone with an even, parallel lamination contains mainly well-sorted pyroxene, feldspar, and basalt grains, and only subordinate amounts of glass altered to palagonite or clay. Contacts between the sandstone and yellowish-brown zeolitic mudstone are sharp, but commonly cut across laminations in the sandstone. The sandstone is interpreted as being epiclastic and nonturbidite, rather than pyroclastic or hyaloclastic, and probably was transported and reworked by slumping and bottom currents. The coarser grains in the mudstone that were glass are now largely clots of phillipsite. The mudstone may have been pyroclastic, or mixed pelagic and pyroclastic, in origin. 
Figure 1. Coarse-grained basalt, Mariana Basin. Partly-altered, anhedral and subhedral labradorite (light) and augite (dark), minor chlorite and magnetite. Gray area to right of scale bar is banded montmorillonite that has replaced glass (7-61-0-2, 2-107 cm; Cretaceous; plane light; scale bar $1.0 \mathrm{~mm}$ ).

Figure 2. Basalt, Mariana Basin. Subhedral labradorite showing Carlsbad and albite twinning is altered in patches. Subordinate enhedral magnetite and subhedral augite. Gray masses at right and left center, left of scale bar, and elsewhere are montmorillonite that has replaced glass (7-61-0-2, 2-107 cm; Cretaceous; crossed polarizers; scale bar $1.0 \mathrm{~mm}$ ).
Figure 3. Basalt, Mariana Basin. Alteration of groundmass glass (left of scale bar), feldspar (center), and pyroxene (upper right) by radiating bundles of acicular montmorillonite and platy chlorite and biotite (7-61-0-2, 2-107 cm; Cretaceous; crossed polarizers; scale bar 0.1 $\mathrm{mm})$.

Figure 4. Altered basalt, Eauripik Ridge. Laths are montmorillonite and chlorite pseudomorphic after plagioclase. Opaque grains in right center are of iddingsite after olivine. Part of groundmass is bleb-shaped clear masses of pale green montmorillonite (right end of scale bar and elsewhere), and remainder is plumose masses of chlorite, epidote (?), and biotite (left end of scale bar and elsewhere) (7-62-0-8-cc; Oligocene; plane light; scale bar $0.1 \mathrm{~mm}$ ). 

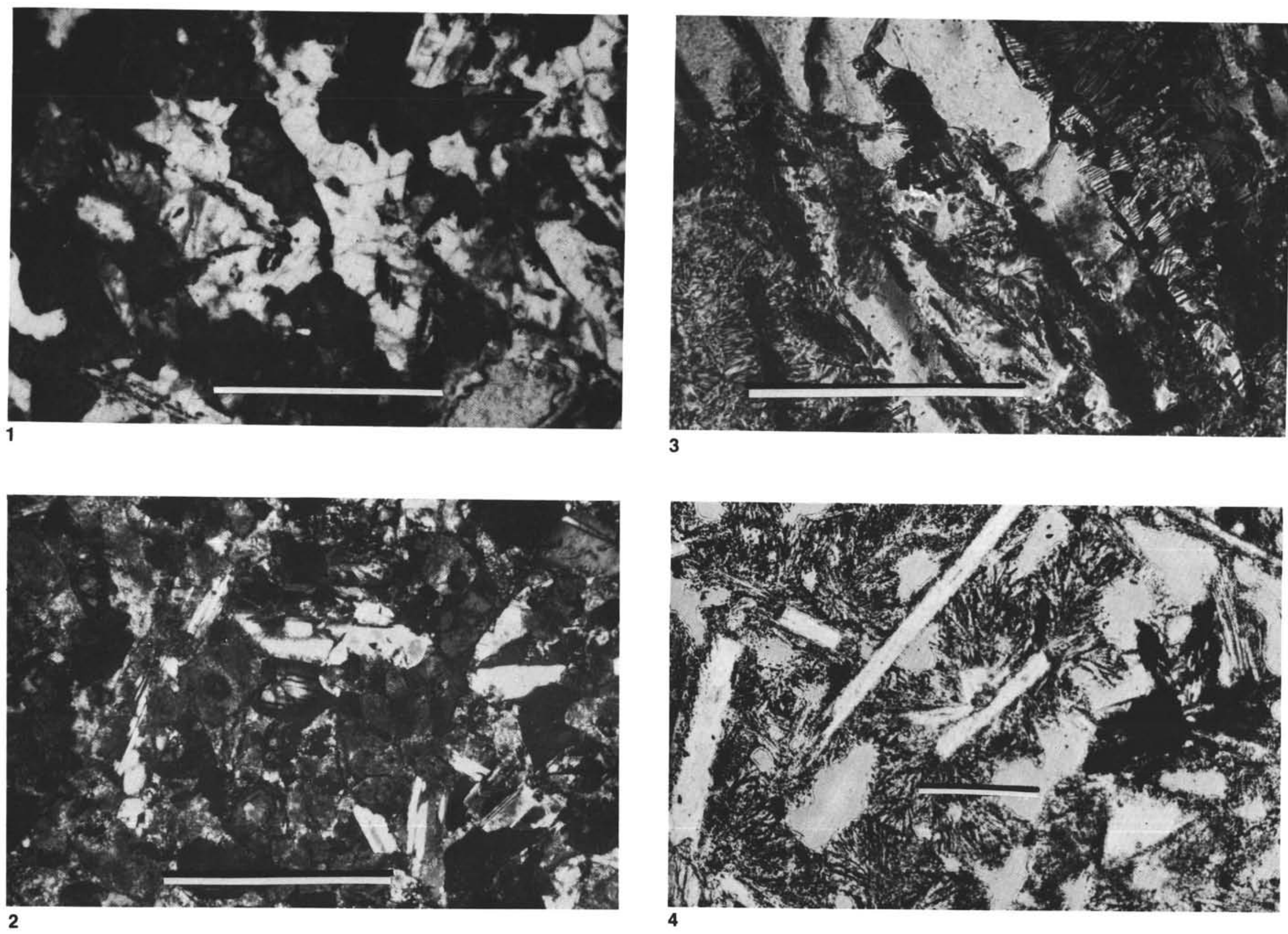
Figure 5. Altered vesicular basalt, Eauripik Ridge. Vesicules (upper right; left end of scale bar) rimmed with chlorite and filled with granular analcite. Masses of pale green montmorillonite seemingly intrude vesicules. Feldspar microlites rimmed with chlorite and biotite (7-62-0-8-cc; Oligocene; plane light; scale bar $1.0 \mathrm{~mm}$ ).

Figure 6. Altered basalt, Eauripik Ridge. Altered plagioclase lath (left end of scale bar), from which blades of chlorite and epidote (?) radiate. Pale green bleb (right end of scale bar) has radial blades at edge (pseudo-isogyre) and central mosaic filling of montmorillonite (7-62-0-8-cc; Oligocene; crossed polarizers; scale bar $0.1 \mathrm{~mm}$ ).
Figure 7. Basalt, East Caroline Basin, Glomerocryst of euhedral labradorite in groundmass of labradorie laths, pyroxene microlites, and plumose montmorillonite (7-63-0-11, 1-23 cm; Oligocene; crossed polarizers; scale bar $1.0 \mathrm{~mm}$ ).

Figure 8. Basalt, East Caroline Basin. Glomerocryst of enhedral labradorite (lower left). Phenocrysts at top are olivine pseudomorphed by serpentine (left), and pyroxene (center). (7-63-0-10, $1-38 \mathrm{~cm}$; Oligocene; plane light; scale bar $1.0 \mathrm{~mm}$. 

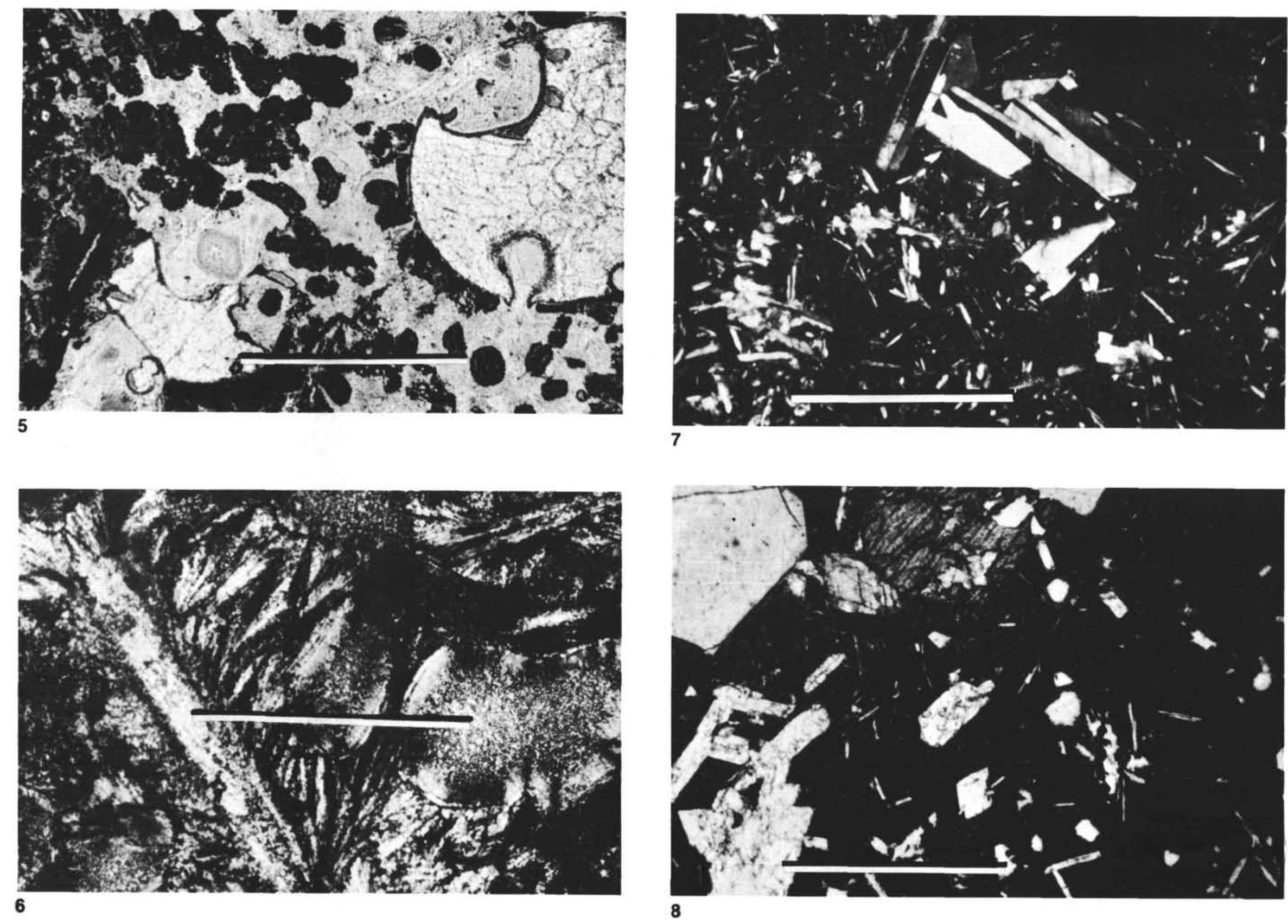
Figure 9. Basalt, East Caroline Basin. Glomerocryst of feldspar phenocrysts that apparently had been partly resorbed, and now have enhedral over growths (7-63-0-10, 1-38 cm; Oligocene; plane light; scale bar $0.1 \mathrm{~mm}$ ).

Figure 10. Same as Figure 9, crossed polarizers.
Figure 11. Basalt, Central Pacific Basin. Plagioclase microlites with interstitial clay and iron oxides. Vesicule at left of scale bar is lined with acicular pale green montmorillonite and filled with dark brown ferromanganese-stained clay. Vesicule at upper right unfilled (7-66-0-9, 3-50 cm; Cretaceous; plane light; scale bar $0.1 \mathrm{~mm}$ ).

Figure 12. Basalt, Central Pacific Basin. Corroded, altered feldspar microlites with pliotaxitic texture. Vesicule at upper right filled with pale green montmorillonite (7-66-0-10-cc; Cretaceous; plane light; scale bar $0.1 \mathrm{~mm}$ ). 

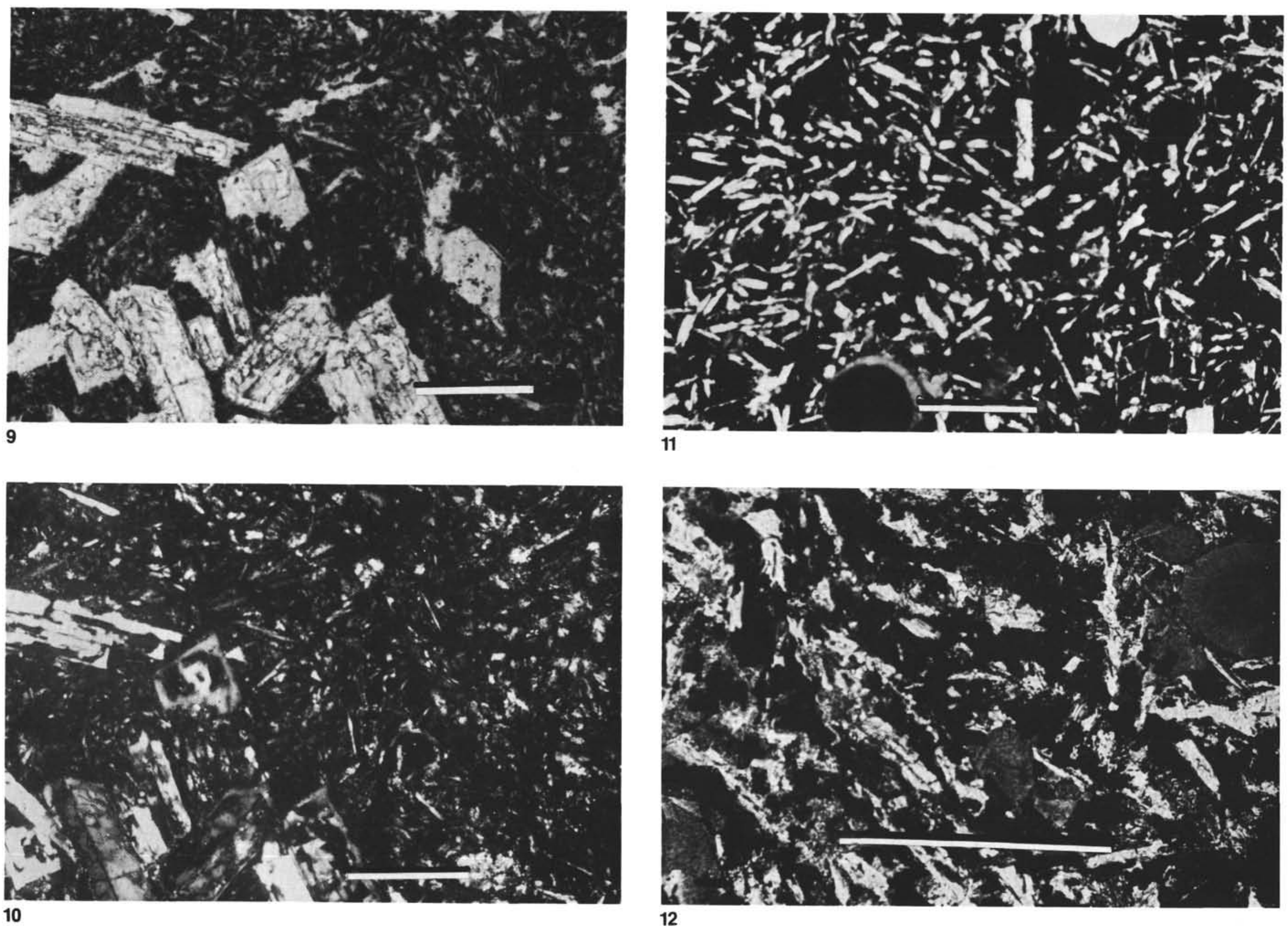
Figure 13. Dolomite, Eauripik Ridge. Dolomite rhombs replacing foraminiferal nannofossil chalk. Several partial tests of foraminifers and patches of micrite remain. Ghost of test wall in rhomb at right end of scale bar (7-62-0-1; Oligocene; plane light; scale bar $0.1 \mathrm{~mm}$ ).

Figure 14. Contact metamorphism of limestone xenolith, East Caroline Basin. Vug near contact of fragment of chalky limestone ingested by basalt. Note foraminifer outlines in upper right and lower right corners. Square prismatic grains (scapolite?) pseudomorphed by mosaics of montmorillonite rosettes and rimmed by green chlorite blades that become pale brown toward the center of the vug (7-63-0-10, 1-32 cm; Oligocene; plane light; scale bar $0.1 \mathrm{~mm}$ ).
Figure 15. Contact metamorphism of limestone xenolith, East Caroline Basin. Similar to Figure 14; another fragment, showing opaque rim of hematite and ferromanganese oxides between altered basalt (behind scale bar) and vug (7-63-0-10, 1-63 cm; Oligocene; plane light; scale bar $0.1 \mathrm{~mm}$ ).

Figure 16. Hyaloclastite, Central Pacific Basin. Golden-brown palagonite grains (dark), rimmed and cemented by zeolite (light), with matrix of montmorillonite and iron oxide (gray). (7-66-0-9, 1-96 cm; Cretaceous; crossed polarizers; scale bar $0.1 \mathrm{~mm}$ ). 

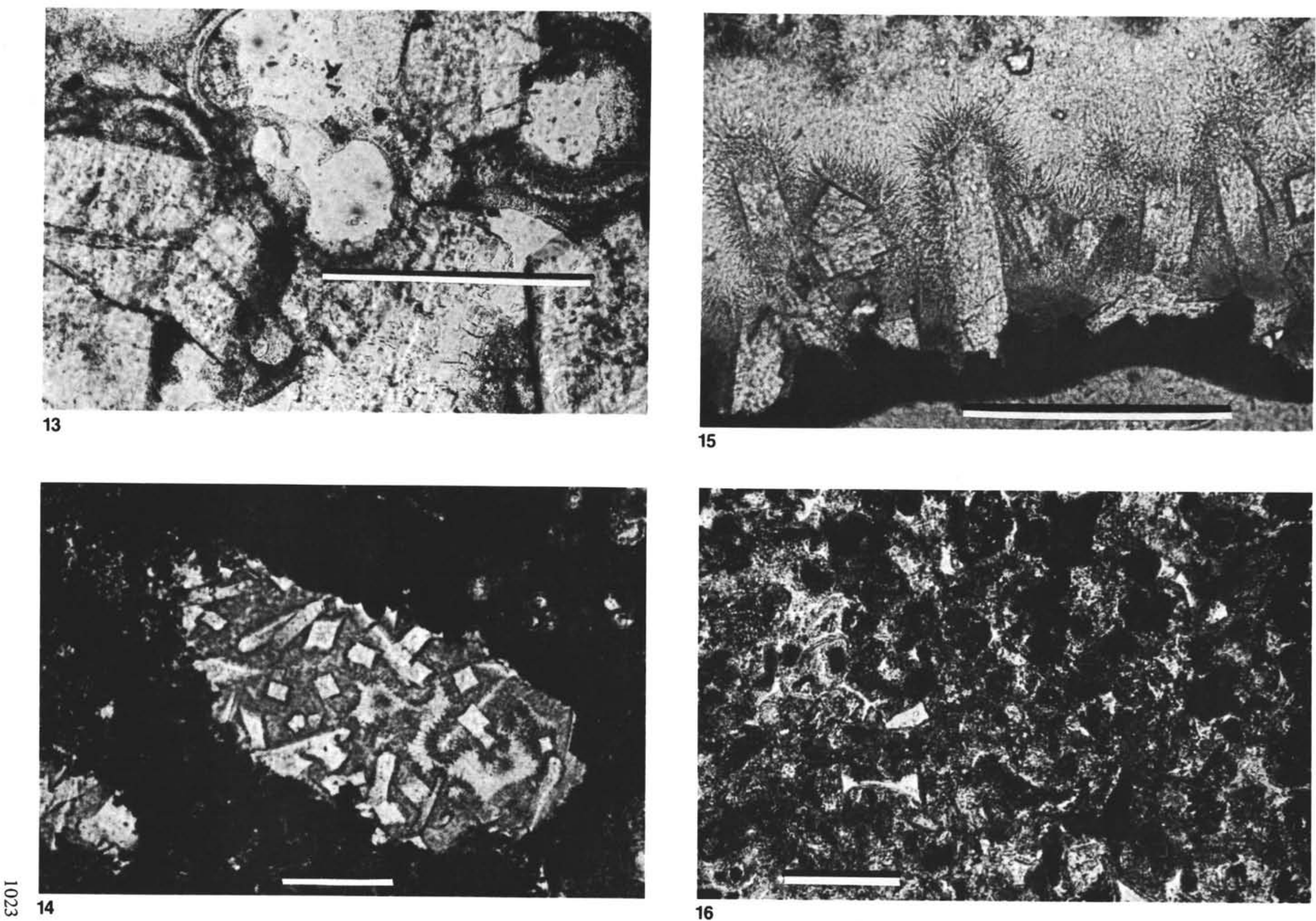
Figure 17. Hyaloclastite, Central Pacific Basin. Irregular lens of ferromanganese oxide-rich clay in mass of grains of palagonitized glass bound by zeolites and clay (7-66-0-9, 3-88 cm; Cretaceous; plane light; scale bar $0.1 \mathrm{~mm}$ ).

Figure 18. Manganese-rich hyaloclastite, Central Basin. As Figure 17, other areas showing relationship of black ferromanganese clay to hyaloclastite grains (7-66-0-9, 3-88 cm; Cretaceous; plane light; scale bar $0.1 \mathrm{~mm}$ ).
Figure 19. Manganese-rich hyaloclastite, Central Basin. As Figure 17, other areas showing relationship of black ferromanganese clay to hyaloclastite grains (7-66-0-9, 3-88 cm; Cretaceous; plane light; scale bar $0.1 \mathrm{~mm}$ ).

Figure 20. Volcanic sandstone, Hawaiian Arch. Smear slide of fraction $>62 \mu$. Largest grains are altered glass (gray; right of scale bar, center, upper right, left edge). Other grains are pyroxene (clear, left of scale bar), phillipsite (rosette, below scale bar), radiolarian fragments (right and left of large opaque grain in lower right), and basalt grains (opaque). (7-67-1-2-cc; Lower Eocene (?), plane light; scale bar 1.0 $\mathrm{mm}$. 

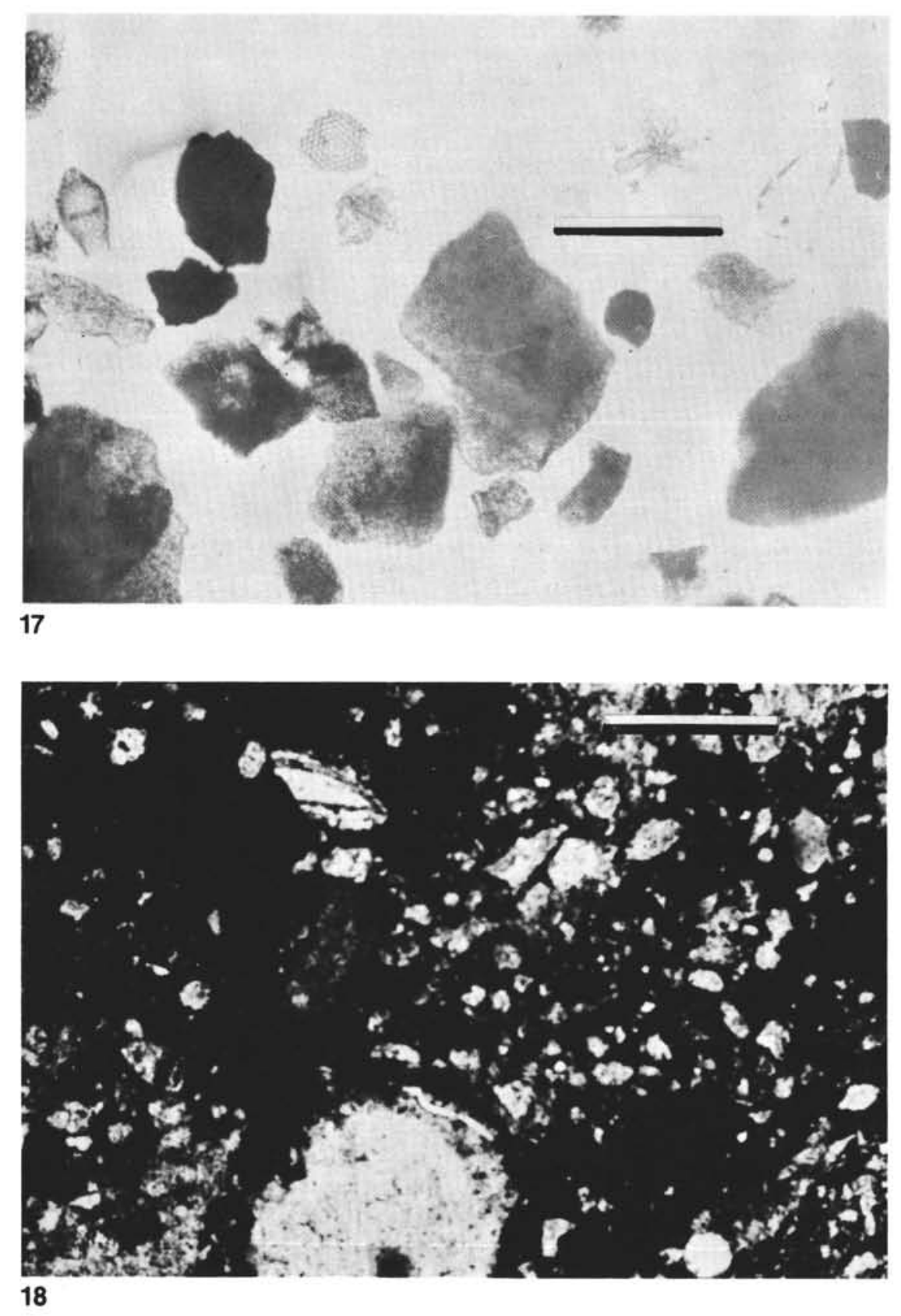
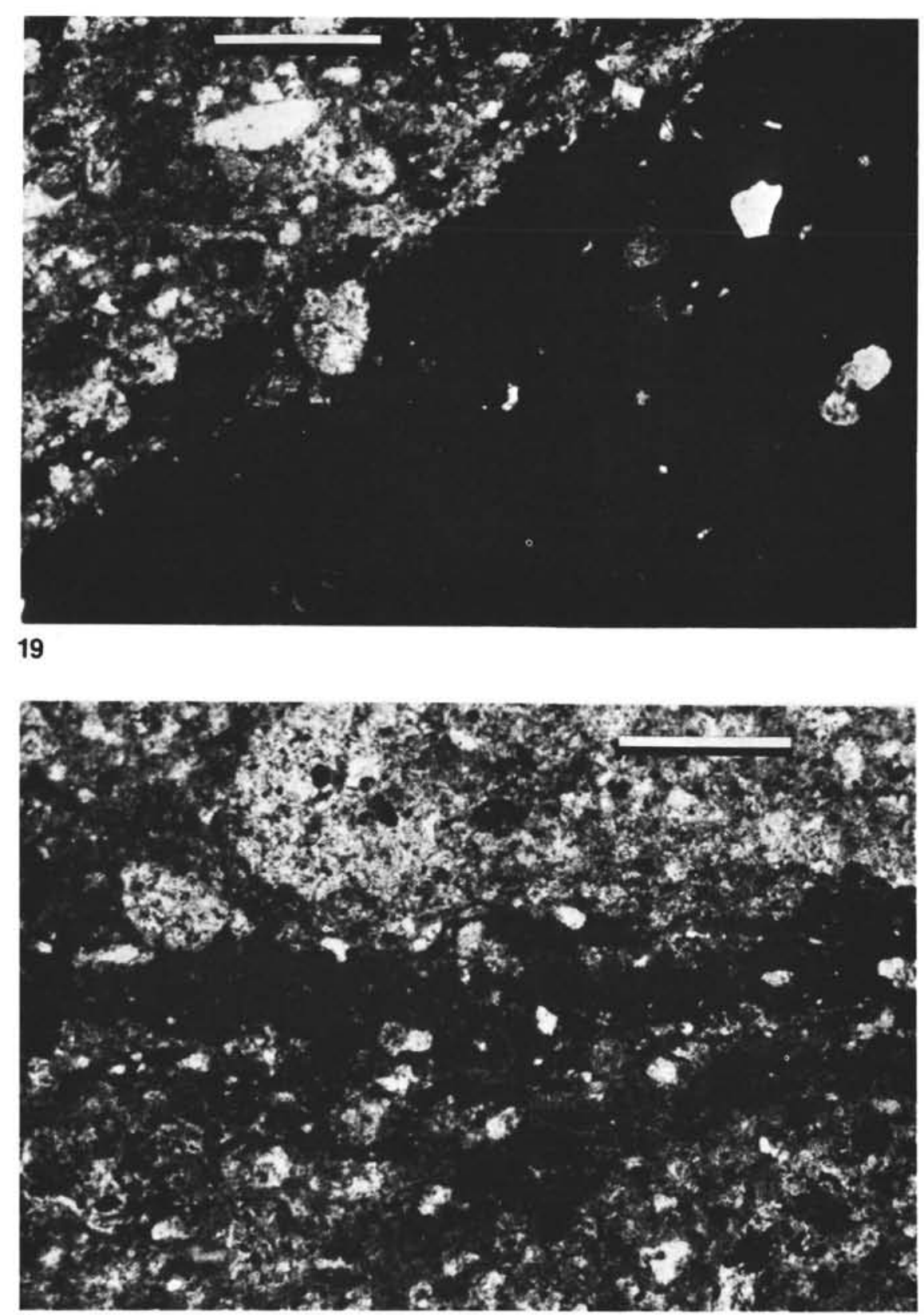